\title{
インターレース加工に関する研究
}

（第 4 報）インターレーサ内における系の姿勢および糸の位置と交絡数の関係

$\begin{array}{ccccc}\text { 福井大学工学部 } & \text { 家 } & \text { 元 } & \text { 良 } & \text { 幸 (会員) } \\ \text { " } & \text { 蝶 } & \text { 野 } & \text { 成 } & \text { 臣 ( " ) } \\ \text { " } & \text { 田 } & \text { 中 } & \text { 孝 } & \text { 幸 ( " ) }\end{array}$

\section{Study on Interlaced Yarn}

\section{Part 4 : Yarn Posture in Interlacer, and Relation between}

\section{Yarn Positions and Number of Tangles}

\author{
Yoshiyuki Iemoto, Shigeomi Chono and Takayuki Tanaka, \\ Faculty of Engineering, Fukui University, Fukui
}

\begin{abstract}
The yarn posture in an interlacer is investigated by using a still camera to take photographs of yarns on interlacing process and then by analyzing statistically yarn positions by a micro-computer as a fundamental experiment to clarify the yarn motion in the interlacer. The relations between the yarn positions in the interlacer and the number of tangles are also discussed. Results are as follows.

(1) The cross section of yarn path is divided into 6 areas and the yarn positions within each area are examined in the yarn axial direction in order to analyze the yarn posture in the interlacer. As a result, the yarn posture has no distinctive feature in this experiment.

(2) Yarns are located evenly on both sides of the air jet axis and traverse frequently the air jet at the air pressure ranging from 2 to $4 \mathrm{~kg} / \mathrm{cm}^{2}$. However, many opening and tangling parts are not produced because of the low air pressure. Yarns are located on one side of the air jet axis and the frequency of yarn traverses is small at the high air pressure of $5 \sim 7 \mathrm{~kg} / \mathrm{cm}^{2}$. The reason of a small number of tangles at low air pressure is different from that at high air pressure. Hence, taking the change of not only the air pressure but also the yarn motion into account makes it easy to understand the variation of the number of tangles which takes the maximum value at the air pressure of $4.5 \mathrm{~kg} / \mathrm{cm}^{2}$.

(3) The yarn positions become one-sided and the frequency of traversing the air jet decreases as the yarn speed increases. It is considered that this decrease causes the number of tangles not to be simply in inverse proportion to the yarn speed.

(4) As the feed ratio increases and the resultant yarn tension decreases, the number of tangles decreases since the yarn does not frequently traverse the air jet. In the case of the small feed ratio, the yarn is restricted in its movements near the center of the yarn path and consequently traverses the air jet very often. However, many tangling parts are not produced owing to the large yarn tension. Hence, the number of tangles is maximum when the feed ratio is about $1 \%$.

(Received September 1, 1987)

\section{摘要}

目的 インターレーサ内の系の運動を明らかにするための基礎実験として, 加工時の系をスチールカメラで複数回に わたって撮影し, 采の位置をコンピュータで統計的に処理することにより, インターレーサ内の系の姿勢について解析す る. 又, 系の位置と交絡数の関係についても検討する.
\end{abstract}


成果 (1) 系の姿勢の解析には, 系道断面を6 個のエリアに分割し各エリアにおける糸の位置を糸軸方向に調べる方 法を用いた．その結果，本研究範囲内ではインターレーサ内の系の姿勢に際立った特徵は見られない.

(2) 空気压が $2 \sim 4 \mathrm{~kg} / \mathrm{cm}^{2}$ の範囲では, 系は空気噴流軸の左右に均等に位置し頻繁に噴流を横切る. しかし, 空気圧が 小さいために糸を充分開繊または交絡させることができない. 空気圧が $5 \sim 7 \mathrm{~kg} / \mathrm{cm}^{2}$ と大きい場合，糸は噴流軸の片側に 位置し噴流を横切る回数は少ない. すなわち, 空気圧の小さい範囲と大きい範囲での交絡数の少ない原因は異なる. 従っ て, 空気圧の変化だけでなく糸の運動も考慮すれば, 空気圧が $4.5 \mathrm{~kg} / \mathrm{cm}^{2}$ のとき最大となる交絡数の変化を説明できる.

（3）系速の増加と共に糸の位置に偏りが生じ，系が空気噴流を横切る回数は隇少する. 交絡数と系速が単純に反比例関 係で表されないのはこれが原因であると考えられる。

(4) フィード率の増加と共に系張力が減少し，系が空気噴流を横切る回数は隇少するため，交絡数も減少する．フィ一 ド率が小さい場合，系の運動は系道の中心に制限されるため頻繁に噴流を横切るが，系張力が大きいので交絡部はあまり 生じない. 従って, フィード率がおよそ1\%で交絡数は最大となる。

(昭和62年 9 月 1 日受理)

\section{1. 緒言}

著者らは，インターレース加工の原理の解明を目 的とし, 空気圧, 空気流量, 系速, フィード率が交 絡数と系張力に及ぼす影響について調べた1.2). 又, インターレース系の生成過程をモデル実験により説 明した ${ }^{3.4)}$.これらの研究は，主に加工条件と生成さ れたインターレース系との関係を扱ったものであ る. 加工原理の解明には, 加工時の糸の運動に関す るデー夕は不可欠であると考えられる.系の運動は, 系道での空気力に最も強く影響される．そこで前 報5では，実際に使用されているインターレーサを 相似的に拡大したインターレーサを用いて，系道管 内壁上の空気の圧力分布と内壁近傍の流速分布を測 定することにより, 系道の流れ場について検討した.

本報では，インターレーサ内の糸の運動を明らか にするための基礎実験として，加工時の糸をスチー ルカメラで複数回にわたって撮影し，系の位置をコ ンピュータで統計的に処理することにより，インタ ーレーサ内の系の姿勢について解析する. 又, 系の 位置と交絡数の関係についても言及する.

\section{2. 実験装置および方法}

試料系は，ポリエステルのマルチフィラメントの 原糸（150 d/48 f） を 1 段ヒートセットした仮撚加 工糸である.

本実験で使用したインターレーサを図 1 に示す. 糸道は円筒形で, 直径, 長さはそれぞれ 4, $21 \mathrm{~mm}$ である．空気噴射ノズルは系道に対して垂直に 1 個

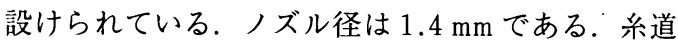
での系を撮影するため，糸道管を肉厚 $1 \mathrm{~mm}$ のガラ ス管に取り替えた.インターレーサを含む系走行装 置については, 前報1.2) と同様であるので割愛する.

四 2 に写真撮影装置の概略を示す４４枚の鏡(2) (5)を図のように配置することにより，インターレー

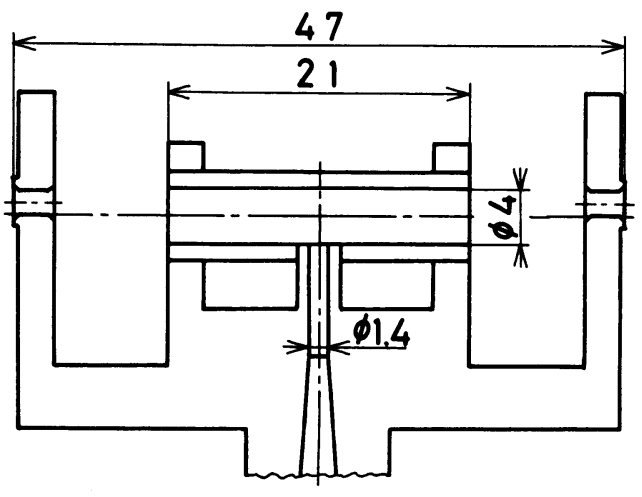

四 1 インターレーサ

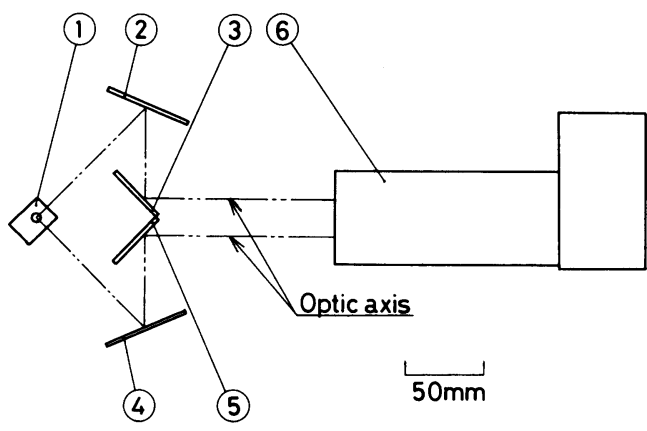

(1) インターレーサ

(2) (5) 鏡

(6) スチールカメラ

図 2 写真撮影装置

サ(1)の 2 方向からの像を同一時刻に 1 台のスチール カメラ6(6で撮影することができ，その結果系の 3 次 元的な位置を知ることが可能となる. 撮影した写真 の一例を図 3 に示す.ただし, 空気圧 $p=4 \mathrm{~kg} / \mathrm{cm}^{2}$, 糸速 $v=200 \mathrm{~m} / \mathrm{min}$, フィード率 $F=1 \%$ であ. 糸の進行方向は右から左である．写真上部をイン夕 ーレーサの平面図，下部を正面図とする。このよう な写真を 1 種類の加工条件に対して200枚撮影し, それらの平面図, 正面図からインターレーサ内の糸 の位置をデジタイザによりコンピュータに入力し 


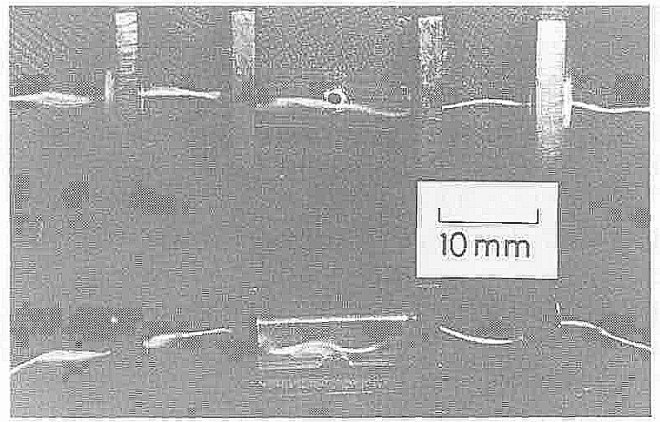

図 3 糸の)写真の一例 $\left(p=4 \mathrm{~kg} / \mathrm{cm}^{2}, y=200 \mathrm{~m} / \mathrm{min}\right.$, $F \equiv 1 \%$
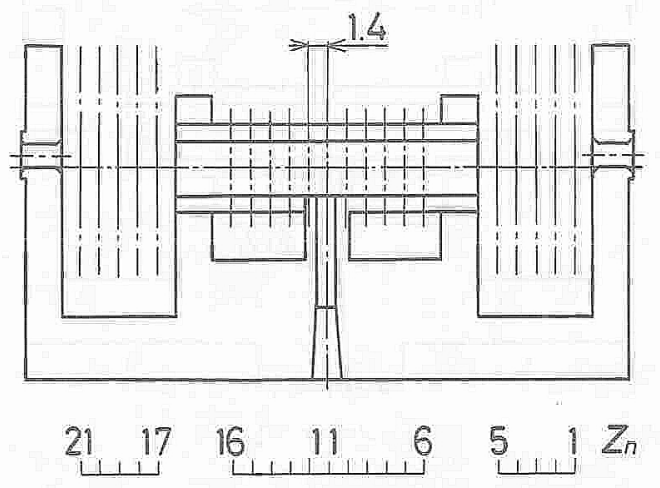

図 4 測是位置

t. 糸肪開瀻している場合その中央部の位置芫入力

し, 個々のアィラメントを解析の刘象と㹥しなかっ

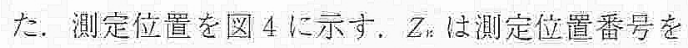
表し，糸の進故问に取っている. $Z_{n}=6 \sim 16$ は 系道内，その他は糸速外で，昰気噴射ノズルの位置 故 $Z_{n}=11$ だある.

系道管での光の庫折により, 写真士の糸の位置は

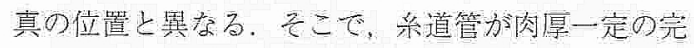

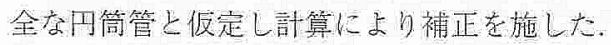

加工条件㛎, 然気圧 $p=2 \sim 7 \mathrm{~kg} / \mathrm{cm}^{2}$ で 1 $\mathrm{kg} / \mathrm{cm}^{2}$ 間隔，系速 $v=100 \sim 500 \mathrm{~m} / \mathrm{min}$ で 100

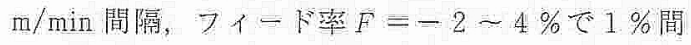
隔でる。

\section{3.結果および考察}

\section{1 糸の洮勢}

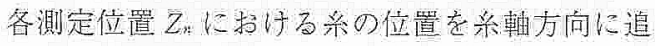
跡すれば，系の姿攀老明ら加にることがでるる。

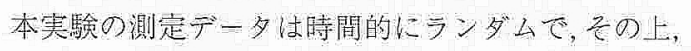
撮影した200本の糸 1 本 1 本について解析すること

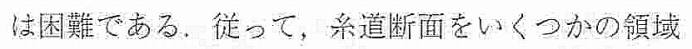
に分割L，同二領域两に位置する複数本の杀につい てまとまった取扱い存したほうが全体の傾向を把握

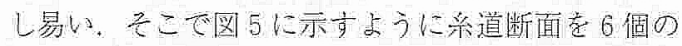
エリアに等面積分割した．空気噴射つズルの位置は 图の下側である。来道外に扔いては，系道に扔ける 分割の外側に 4 個のエリ

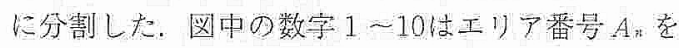

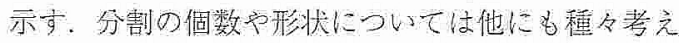
られるが，空気噴射ノズルの位置や個数予よび糸道 直徍など考虑して图のような分劃にした。

図 6 に, 测定位置 $Z_{n}=11$ での王りア $A_{n}$ に糸か 存在する確率 $\hat{P}$, と陚料本数 $N$, との関係丞示吉. 加 工条件空気压 $p=4,6 \mathrm{~kg} / \mathrm{cm}^{2}$, 系速 $v=200$, $500 \mathrm{~m} / \mathrm{min}$, フィード率 $F=-2,1,4 \%$ である. いずれの加工条件の場合も， $N_{s} \geqq 150$ で $\hat{P}_{*}$ ははに 一定值に收束していることがわかる。従って，試料 本数力5200本の解析下克分大゙あるいえる.

条か゚インターレーサ孝通過する際に取る姿勢は主

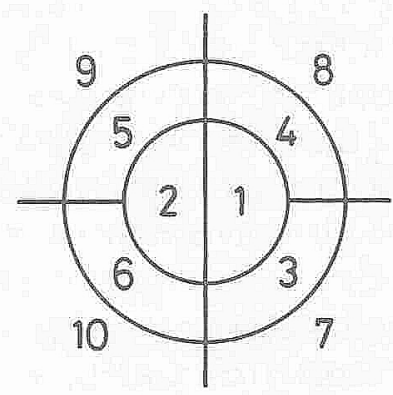

図5Ｉリ分割

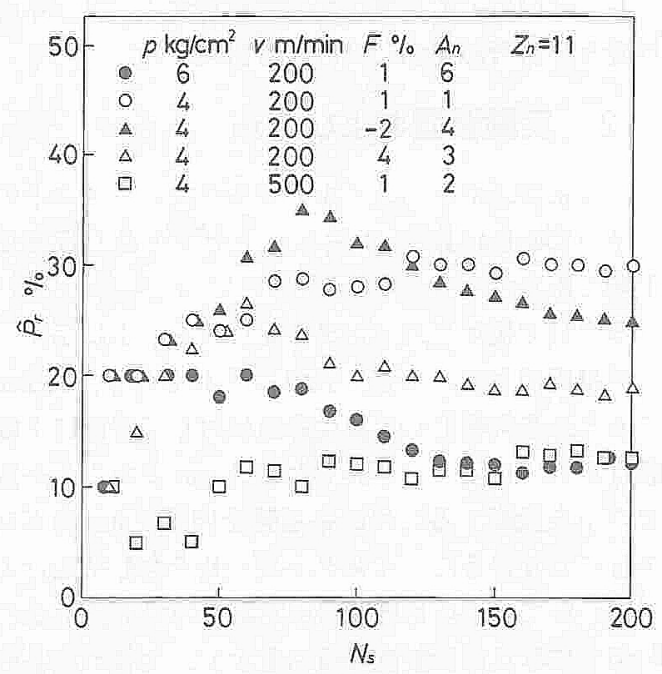

図 6 試数本数の検証 
に空気力によって支配されると考えられるため，系 に作用する空気力の最も大きい空気噴射ノズルの位 置 $Z_{n}=11$ での系の位置とその他の $Z_{n}$ での系の位置 を調べれば，系の姿勢を知る手がかりになる．図 7 (a), (b)に, $p=4 \mathrm{~kg} / \mathrm{cm}^{2}, v=200 \mathrm{~m} / \mathrm{min}, F=1 \%$ の場合の糸の姿勢を示す. 図(a), (b)の間の数值は $Z_{n}$ である．図(a)は, 200本の糸のうち $Z_{n}=11$ の工 リア番号 $A_{n}=1$ の領域に位置した糸のみを抽出し, これらの系の位置を個々の $Z$ ににおいて重ね書きし た図である. 図(b)は， $A_{n}=5$ の場合の結果である. 代表として挙げた $Z_{n}=3 ， 6 ， 9$ はそれぞれヤー ンガイドと系道端の間, 系道端近傍, 系道端と空気 噴射ノズル位置の間に相当し， $Z_{n}=13 ， 16,19$ は $Z_{n}=11$ に関するこれらの対称な位置である. 図よ り $Z_{n}=9 ， 13$ における糸の位置の分布形状は， $Z_{n}$ $=11$ での形状と似ていることがわかる. $Z_{n}=6$, 16の系道端近傍では, 系の位置の分布は広がるが噴 流軸付近に集まり系道の左右端にはあまり位置して いないことから，系は系道の中心付近で主に噴流軸 に平行な運動をしていると予想される，系道外であ る $Z_{n}=3,19$ の測定位置になると特定の傾向は示 さず糸は全域に位置している。

図 8(a), (b)k, $p=6 \mathrm{~kg} / \mathrm{cm}^{2}, v=200 \mathrm{~m} / \mathrm{min}, F$ $=1 \%$ の場合の系の姿勢を示す. $Z_{n}=11$ における エリア番号はそれぞれ $A_{n}=2 ， 5$ である. 図のよ うに $p$ が大きい場合， $Z_{n}=9,13$ における系の位

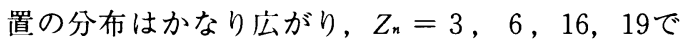

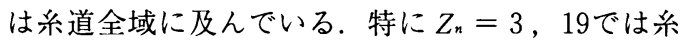
道外である $A_{n}=7$ １0にかなり位置しており，系 の運動は図 7 に比して激しいことがわかる.

図 9 (a), (b)に, $p=4 \mathrm{~kg} / \mathrm{cm}^{2}, v=500 \mathrm{~m} / \mathrm{min}, F$ $=1 \%$ の場合の系の姿勢を示す. $Z_{n}=11$ における エリア番号はそれぞれ $A_{n}=1 ， 5$ である. 図より， 糸の姿勢に特異な傾向は見られず図 7 と似ている.

図10(a)，(b)に, $p=4 \mathrm{~kg} / \mathrm{cm}^{2}, v=200 \mathrm{~m} / \mathrm{min}, F$ $=-2 \%$ の場合の系の姿勢を示す. $Z_{n}=11$ におけ るエリア番号はそれぞれ $A_{n}=1 ， 5$ である. 四10 の場合, 図 $7 \sim 9$ に比して糸張力は大きい.つまり 空気力による糸の運動がかなり制限されるため, $Z$ n $=11$ における系の位置の分布形状が他の $Z_{n}$ でも残 っていることがわかる. ただし系道外の $Z_{n}=3$ ， 19ではほぼ全域に広がっている。

以上図 7 １0より，加工条件によって系の姿勢に わずかな差はあるが，際立った特徴は見られない.
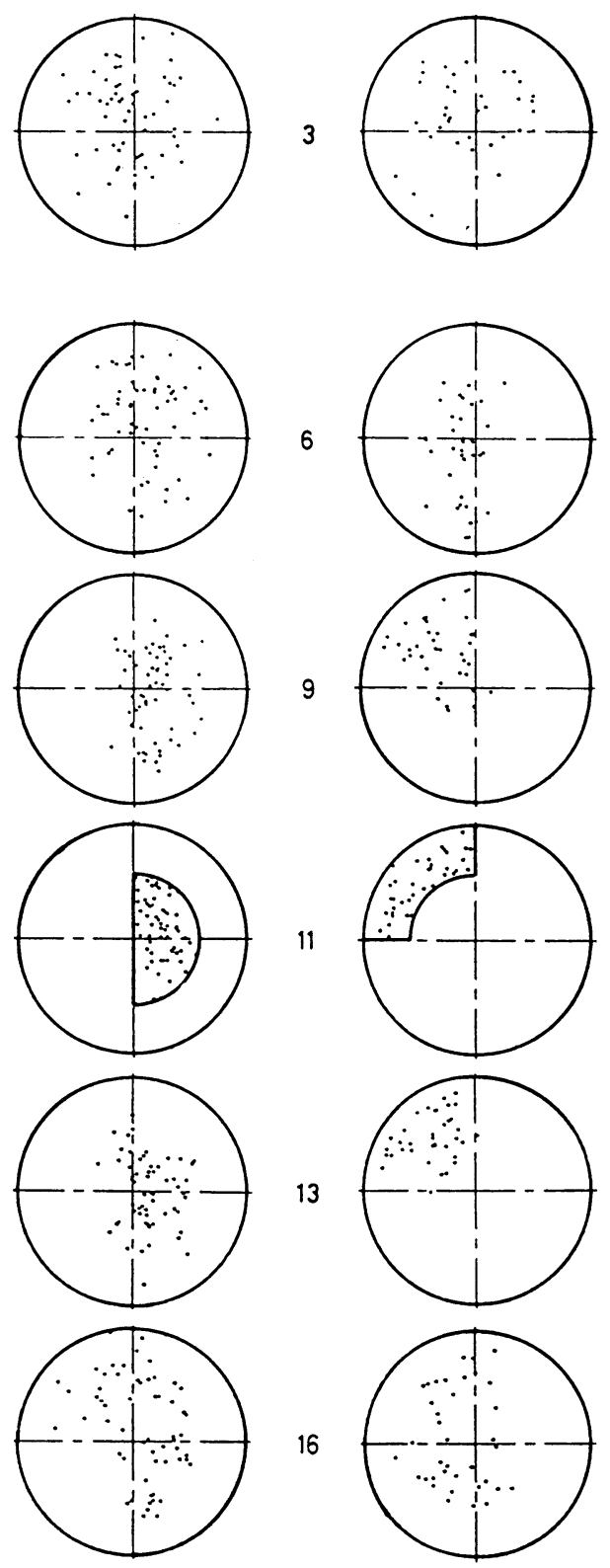

11

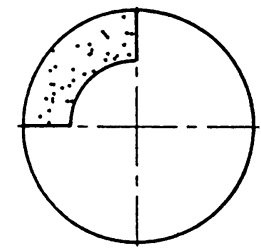

13
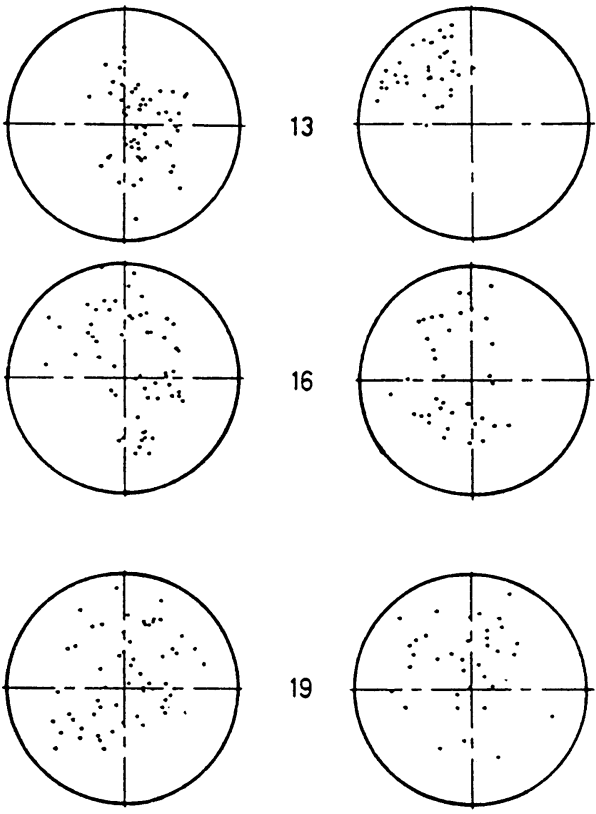

(a) $A_{n}=1$

(b) $A_{n}=5$

図 7 系の姿勢 $\left(p=4 \mathrm{~kg} / \mathrm{cm}^{2}, v=200 \mathrm{~m} / \mathrm{min}, F=\right.$ $1 \%)$ 

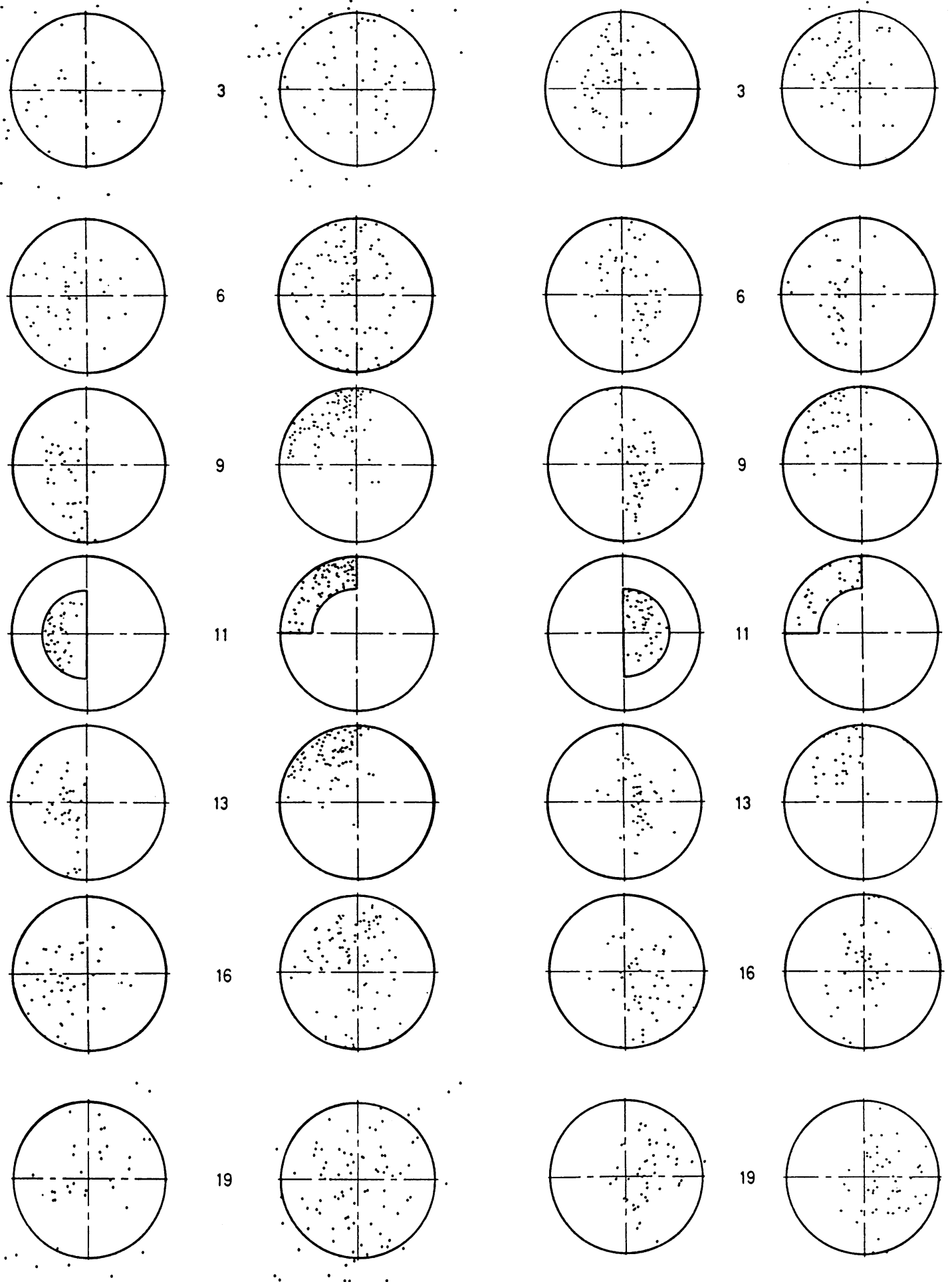

(a) $A_{n}=2$

(b) $A_{n}=5$

(a) $A_{n}=1$

(b) $A_{n}=5$

図 8 系の姿勢 $\left(p=6 \mathrm{~kg} / \mathrm{cm}^{2}, v=200 \mathrm{~m} / \mathrm{min}, F=\right.$ $1 \%)$

図 9 糸の姿勢 $\left(p=4 \mathrm{~kg} / \mathrm{cm}^{2}, v=500 \mathrm{~m} / \mathrm{min}, F=\right.$ $1 \%$ ) 

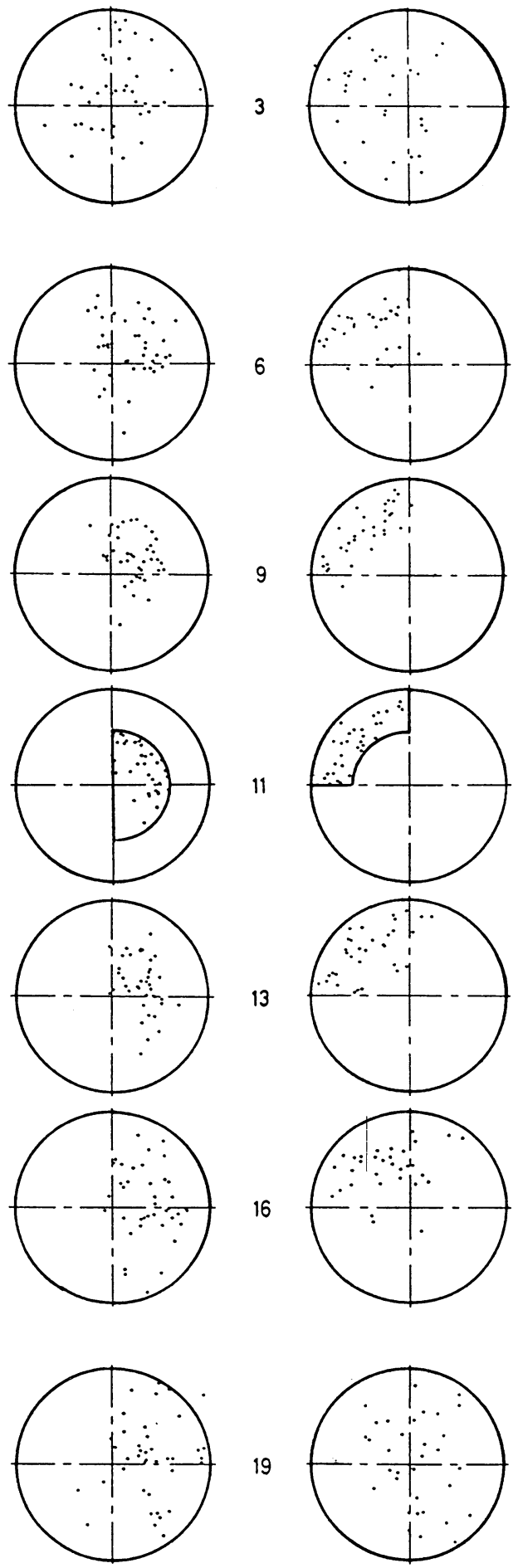

(a) $A_{n}=1$

図10 系の姿勢 $\left(p=4 \mathrm{~kg} / \mathrm{cm}^{2}, v=200 \mathrm{~m} / \mathrm{min}, F=\right.$ $-2 \%)$

\section{2 糸の位置と交絡数の関係}

図11(a) (f)に, 空気圧 $p=2,4,6 \mathrm{~kg} / \mathrm{cm}^{2}$, 系 速 $v=200,400 \mathrm{~m} / \mathrm{min}$, フィード率 $F=-2,1$, $4 \%$ の場合の, 一例として測定位置 $Z_{n}=11$ での 200本の系の位置を示す. 図より，系の位置の分布 は加工条件によって異なることがわかる．他の加工 条件や $Z_{n}$ における系の位置をすべて図示すること は困難である，著者らは，インターレース糸のモデ ル実験3.41の結果より, 系の交絡, 開繊は糸が空気噴 流を横切る際に起こることを明らかにした.従って， 交絡部や開繊部の生成には, 系の噴流軸方向の運動 よりも噴流軸に垂直な方向の運動が重要な役割を果

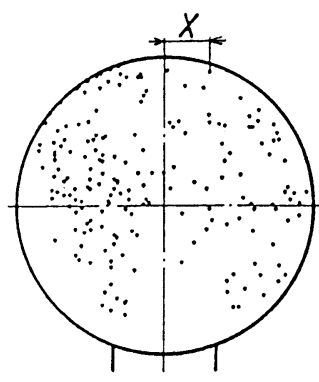

(a) $p=2 \mathrm{~kg} / \mathrm{cm}^{2}$, $v=200 \mathrm{~m} / \mathrm{min}$, $F=1 \%$

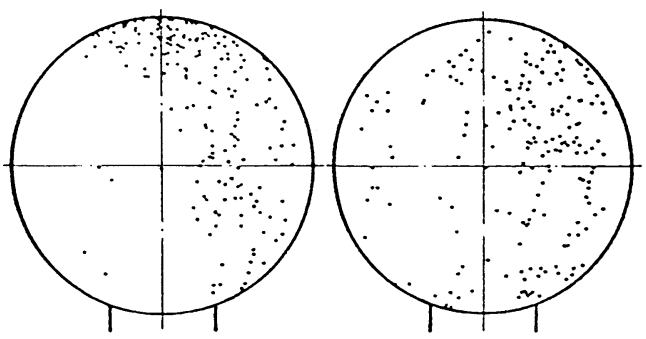

(c) $p=6 \mathrm{~kg} / \mathrm{cm}^{2}$, $v=200 \mathrm{~m} / \mathrm{min}$, $F=1 \%$

(d) $p=4 \mathrm{~kg} / \mathrm{cm}^{2}$, $v=400 \mathrm{~m} / \mathrm{min}$, $F=1 \%$

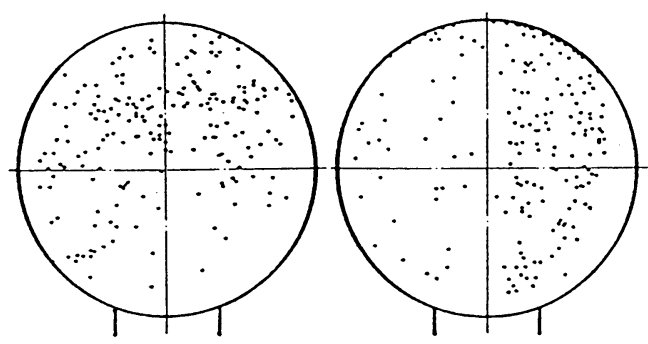

(e) $p=4 \mathrm{~kg} / \mathrm{cm}^{2}$, $v=200 \mathrm{~m} / \mathrm{min}$, $F=-2 \%$

(f) $p=4 \mathrm{~kg} / \mathrm{cm}^{2}$, $v=200 \mathrm{~m} / \mathrm{min}$, $F=4 \%$

図11 系の位置 $\left(Z_{n}=11\right)$ 
していると考えられる. そこで, 図11(a)に示すよう に噴流軸から系までの距離 $x$ を用いることにより， 系の位置の定量的な解析を試みる.200本の系につ いての $x$ の平均値を考えると, 200 本の糸が噴流軸 の左右に均等に位置する場合この値はほぼ 0 に等し く，そうでない場合 0 から離れた值を取る。噴流軸 の左右の区別について考慮する必要はないことか ら，この値の絶対值を取った量 $|\bar{x}|$ を導入する.こ の $|\bar{x}|$ は糸の平均位置（噴流軸に対する系の偏り状 態）を表すことがわかる.

図 12 に, 糸速 $v=200 \mathrm{~m} / \mathrm{min}$, フィード率 $F=1 \%$ の場合の, 系の平均位置 $|\bar{x}|$ と空気圧 $p$ の関係を示 すただし，縦軸には $|\bar{x}|$ を系道半径 $d / 2$ で無次元 化した值を取っている，パラメータは Znである。

図より, $|\bar{x}|$ は $p \leqq 4 \mathrm{~kg} / \mathrm{cm}^{2}$ の範囲では小さいが $p \geqq 5 \mathrm{~kg} / \mathrm{cm}^{2}$ の範囲では比較的大きな值を取り, $p$ $=4 \sim 5 \mathrm{~kg} / \mathrm{cm}^{2}$ を境界として系の位置の分布形状 が異なることがわかる，すなわち， $p$ が小さい場合 系は噴流軸の左右にほほ均等に位置するが, $p$ が 5 $\mathrm{kg} / \mathrm{cm}^{2}$ 以上では系は噴流軸の片側に偏る結果とな っている. 空気噴射ノズルのある $Z_{n}=11$ のプロッ 卜について注目しても同様の傾向が現れており，特 に $p=4 \mathrm{~kg} / \mathrm{cm}^{2}$ で $|\bar{x}|$ は最小值を取っている. $Z_{n}$ の変化について見れば，大部分の $p$ の場合 $Z_{n}=11$ で| $|\bar{x}|$ は最も大きい.これは, 系は $Z_{n}=11$ で偏り 易く，その他の $Z_{n}$ では噴流軸に対し比較的均等に 位置することを示している，ここで，例えば系速 v $=200 \mathrm{~m} / \mathrm{min}$ で交絡数が 100 個 $/ \mathrm{m}$ 生成される場合を 考えると, 交絡部は 1 秒間に 300 個余り生成される

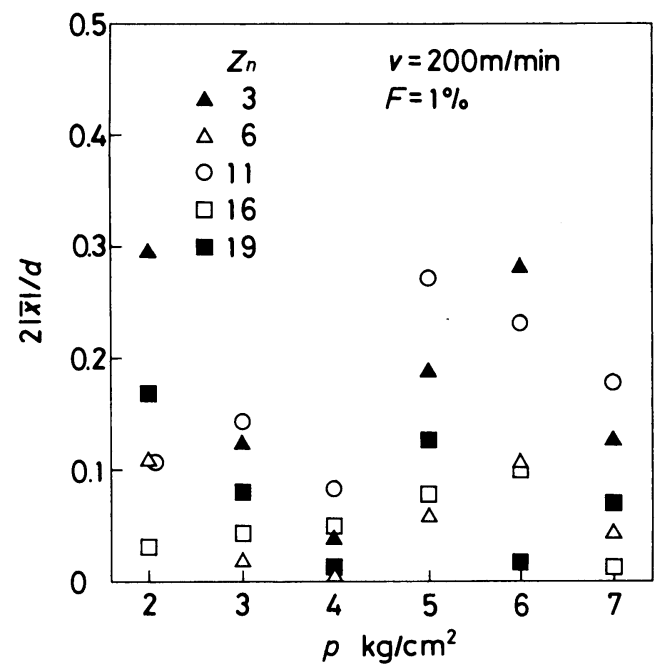

図12 系の平均位置と空気圧の関係
ことになる. 系が空気噴流を 1 度横切ることによっ て1個の交絡部ができるとすれば，糸の空気噴流を 横切る回数も 1 秒間に 300 回余りとなる. 写真撮影 は数秒間隔で200回行った，系の運動が撮影時間に 比して非常に高速であることを考慮すれば，噴流軸 の左右に糸が均等に位置する場合系は頻繁に空気噴 流を横切り，噴流軸に対し糸が偏っている場合は横 切る回数が少ないと考えることができる.すなわ ち,|可|が大きいほど系が空気噴流を横切る回数は 少ない. 前報1の交絡数の変化で, $p$ が $5 \mathrm{~kg} / \mathrm{cm}^{2}$ 付 近で交絡数は急激に減少したが，これは空気力が強 過ぎたため糸が噴流軸の片側で旋回または振動運動 を続ける時間が長く，系が空気噴流を横切る回数が 少ないためである. p が小さい場合も交絡数は少な かったが，これは糸が空気噴流を横切る回数は充分 であるが系を開繊または交絡させる空気力が弱過ぎ たためである．以上のように系の開繊または交絡過 程に空気力の变化だけでなく系の連動の変化をも考 慮に入れると, $p=4.5 \mathrm{~kg} / \mathrm{cm}^{2}$ で最大となる交絡数 の変化について満足な説明を与えることができる.

図 13 , 空気圧 $p=4 \mathrm{~kg} / \mathrm{cm}^{2}$, フィード率 $F=$ $1 \%$ の場合の, 系の平均位置 $|\bar{x}|$ と系速 $v$ の関係を 示す. 図より, 大部分の $Z_{n}$ で $|\bar{x}|$ は $v$ の增加と共 に増加する傾向を示しており，糸の位置に偏りが生 じている. 糸が空気噴流を横切る回数が $v$ に無関係 で一定であれば, 交絡数と $v$ は反比例関係にある. しかし，前報1の結果より両者の関係は必ずしもそ うではなく, $v$ の大きい範囲で交絡数は反比例の関 係に比して低い值を取っている。この原因は上述し

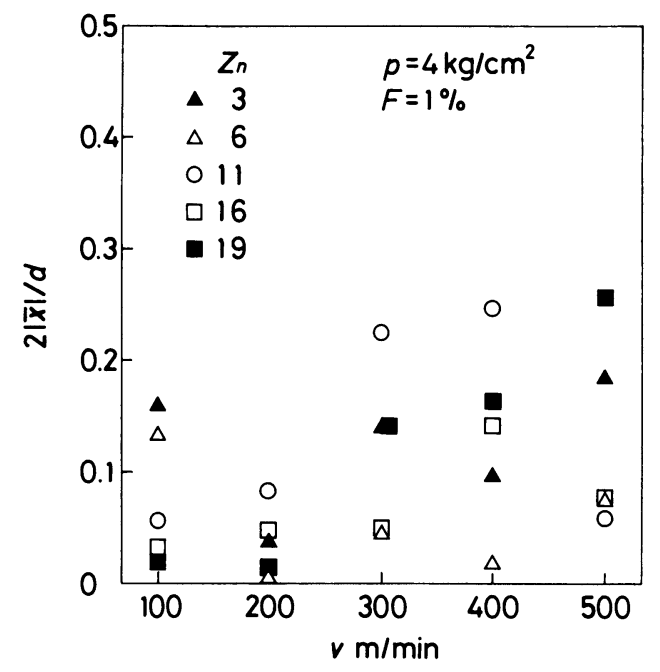

図13 系の平均位置と系速の関係 
た糸の偏りによる空気噴流を横切る回数の減少にあ ると考えられる。ただし，vが増加すればインター レーサ内の糸の運動は激しくなると予想されるた め, 噴流軸に対する糸の位置の偏りの程度が同じで も $|\bar{x}|$ の值としては大きく現れる. 眓13の $|\bar{x}|$ の值 が図12と同程度の值を取るにもかかわらず交絡数の pに対するような大きな变化を示さないのはこのた めであると考えられる。

図14に, 系の平均位置 $|\bar{x}|$ とフィード率 $F$ の関係 を示す. 空気圧 $p=4 \mathrm{~kg} / \mathrm{cm}^{2}$, 系速 $v=200 \mathrm{~m} / \mathrm{min}$ である. 図より, 測定位置 $Z_{n}=3,6,16,19$ で は $F$ の増加と共に $|\bar{x}|$ は減少し, $F=1 \sim 2 \%$ で最 小値を取る.さらに $F$ が増加すると| $\mid$ |は増加する. 従って, $F=1 \sim 2 \%$ で系が最も活発に運動し, 系 張力の高い $F=-2 \sim 0 \%$ や系張力の低い $F=2$ 〜 $4 \%$ 範囲においては糸の運動は制限され, 系の 位置は空気噴流軸の片側に偏っている. $Z_{n}=11$ で は, $F$ の増加と共に $|\bar{x}|$ は増加する傾向を示す， $Z_{n}$ $=11$ では空気力は他の $Z_{n}$ に比して大きいため, $F$ $=2 \sim 4 \%$ では $|\bar{x}|$ は極端に大きな值を示し, 糸の 位置は噴流軸に対し大きく偏っていることがわか る．Fの小さい範囲では糸にかなり大きな張力が働 いているため, 糸が空気噴流を受けても系道の中心 に運動が制限される. 従って, 系の噴流軸からの距 離は小さく, 噴流軸に対し均等に位置し, 系は頻繁 に噴流を横切る.しかし，系張力が大きいために噴 流を受けても充分開㵶されないので交絡数は少な い. 以上のように $F$ の影響についても，系の連動

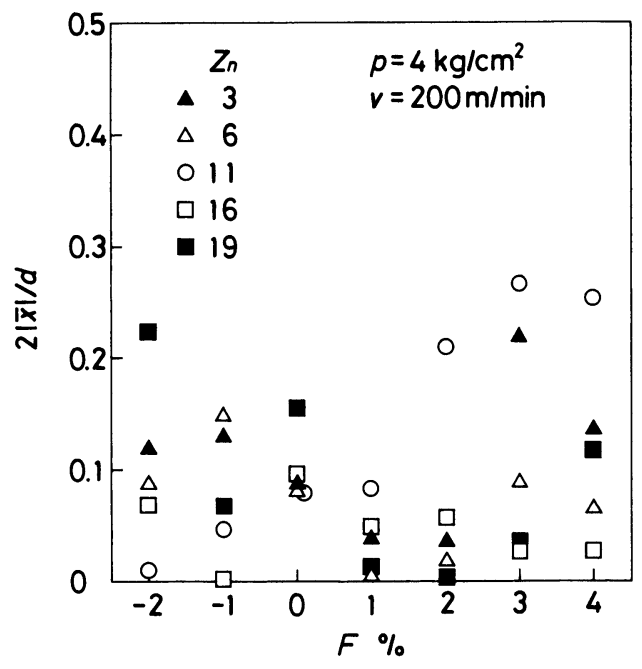

図14 系の平均位置とフィード率の関係
の変化から交絡数は $F=1 \%$ 付近で最大值を取る という前報”の結果を充分説明できる。

\section{4. 結言}

本研究では, インターレーサ内の糸の運動を明ら かにするための基礎実験として，加工時の糸をスチ ールカメラで複数回にわたって撮影し, 糸の位置を コンピュータで統計的に処理することにより，イン ターレーサ内の系の姿勢について解析した. 又, 系 の位置と交絡数の関係についても検討した. 得られ た結果を要約して以下に示す.

（1）系の姿勢の解析には，系道断面を 6 個のエリ アに分割し各エリアの系の位置を糸軸方向に調べる 方法を用いた。 その結果, 本研究範囲内ではイン夕 ーレーサ内の糸の姿勢に際立った特徵は見られな w.

（2）空気圧が $2 \sim 4 \mathrm{~kg} / \mathrm{cm}^{2}$ の範囲では，糸は空 気噴流軸の左右に均等に位置し頻繁に噴流を横切 る.しかし，空気圧が小さいために系を充分開緎ま たは交絡させることができない. 空気圧が $5 \sim 7$ $\mathrm{kg} / \mathrm{cm}^{2}$ と大きい場合, 系は噴流軸の片側に位置し 噴流を横切る回数は少ない. すなわち, 空気圧の小 さい範囲と大きい範囲での交絡数の少ない原因は異 なる. 従って, 空気圧の変化だけでなく系の運動も 考慮すれば, 空気圧が $4.5 \mathrm{~kg} / \mathrm{cm}^{2}$ のとき最大とな る交絡数の变化を説明できる.

（3）系速の増加と共に糸の位置に偏りが生じ，系 が空気噴流を横切る回数は減少する. 交絡数と糸速 が単純に反比例関係で表されないのはこれが原因で あると考えられる。

（4）フィード率の増加と共に糸張力が減少し, 系 が空気噴流を横切る回数は減少するため, 交絡数も 減少する.フィード率が小さい場合, 系の運動は糸 道の中心に制限されるため頻繁に噴流を横切るが， 系張力が大きいので交絡部はあまり生じない，従っ て,フィード率が拈よそ $1 \%$ で交絡数は最大となる.

終りに, 本研究は社団法人日本繊維機械学会学術 奨励金および財団法人繊維工業研究協会の助成を受 けたことを記し，感謝の意を表します。

\section{参考文献}

1）家元, 蝶野, 澤等; 线機誌, 39, T 107 (1986)

2）家元，蝶野，澤岢：㵶機誌, 39, T 115 (1986)

3）家元, 蝶野, 谷田：繊機誌, 39, T 123 (1986)

4) 蝶野, 家元, 谷田; 繊機誌, 40, T 33 (1987)

5）家元，蝶野；緎機誌， 40, T 47 (1987) 